\title{
Attuning a Problem Based Learning Model for Out of School Children using Design-Based Research
}

\author{
Iip Saripah \\ Department of Non-formal Education \\ Faculty of Education, Universitas Pendidikan Indonesia \\ Indonesia \\ iipsaripah@ymail.com
}

\begin{abstract}
The problem of dropout students is closely related with economic weakness of a family, social environment, and the awareness of the importance of education. Concerning dropout students, it is difficult to raise parents' awareness of the importance of education, because from the family perspective, dropout children are expected to become an economic asset to help their family as early as possible. The aim of the present study is to discover the procedure of PBL model implementation in entrepreneurship training for dropout students at CLC (Community Learning Center) Bina Cipta Ujungberung. The study is expected to provide data and information concerning nonformal education institutions which will enable the general population to enter workplace environments and/or independently become entrepreneurs; in order to respond to public needs and to build learning society. This research and development study is conducted for eight month following the preliminary design for the first year. Data is collected through document study, interview, study of primary data, and focus group discussion. The findings show that the following procedures are implemented in the training: tutors review and present problems in which the learners identify problems themselves and find solutions for the problems through experience and practices with various degree of success; learners develop adequate strategy to solve problems through mentoring with the tutors; tutors ask questions to support and encourage learners to finish their tasks; tutor ask learners to discuss and evaluate the solutions to problems. Based on the findings, it is concluded that entrepreneurship training for dropout students can be appropriately delivered using problembased learning.
\end{abstract}

Key words : Entrepreneurship training, Dropout Students, PBL

\section{INTRODUCTION}

Education is a deliberate and systematic effort to create certain learning environment and process which will allow the students to actively develop their potentials to possess religious and spiritual strength, self-control, personality, intelligence, noble character, and skills that are needed by individual citizen, society, and the nation. [1]

One of the purposes of Non-Formal Education Department Laboratory is to increase the availability and accessibility of education services on life skills, workshop and trainings, and entrepreneurship education which are of high quality, competitive, and relevant with the empowerment needs of society, business, and industry; particularly for school dropouts so that they can productively, independently, and professionally work and/or become entrepreneurs.
The government, particularly the Directorate of training and workshop, attempts to produce high quality education which is in line with social needs and problems. One of its endeavors in this matter is issuing the policy of Public Entrepreneurial Education (Pendidikan Kewirausahaan Masyarakat/PKM). PKM program aims to provide high quality entrepreneurial education that is relevant to the needs of the society. Thus, all graduates of the program are expected to be able to work independently or create new jobs, to produce creative and innovative goods and/or services, and to empower local potentials/resources in order to improve life quality of the people and alleviate poverty and unemployment in Indonesia. The policy requires the providers of education (formal, non-formal, and informal) to make Public Entrepreneurial Education (PKM) an essential and inseparable part of education to satisfy public needs of education, including training and workshop.

Training and workshop program is implemented to minimize the problems of unemployment and poverty in Indonesia. Government data [2] shows that the level of unemployment in Indonesia per August 2012 decreases to $6.14 \%$, compared with the number in August 2011 of $6.56 \%$. The data outlines that the remaining number of unemployed citizen in Indonesia per August 2012 is 7.24 million people. The factors causing unemployment in Indonesia include: first, the higher number of jobseekers than the number of available job (discrepancy of supply and demand); second, the discrepancy of jobseekers' competencies and the competencies needed by the market (mismatch of competencies); third, the high number of dropouts and graduates who are not absorbed in labor market or do not work independently due to insufficient skills (unskilled labor); and fourth, the high level of termination of employment.

The problem of school dropout contributes greatly to the level of unemployment. Data shows that the level of school dropout in Indonesia is relatively high. One of the causes of this problem is poverty. Data from Research and Development Bureau of Indonesia's Ministry of Education and Culture [3] reveals that there are 1.7 million children/year drop out of SMK/SMU/MA (senior high school level). This number also includes the graduates of junior high school and senior high school who do not continue their education. Based on the Education for All Global Monitoring report released by UNESCO in 2011, Indonesia ranks 69 out of 127 nations in the Education Development Index. Meanwhile, the latest data from National Body of Planned Family Coordination, there are currently 13,685,324 school dropouts, aged between $7-15$ years 
old. Among this number, 769,235 children (around 6\%) are in West Java province. The Ministry of Labor and Transmigration predicted that there were approximately 2.5 million job opportunities in Indonesia by 2013; which can be utilized to decrease the number of unemployment in the country. The assumption was based on the optimistic 2013 target of economic growth of $6.8 \%$ and on the action plans of all government and private institutions, in central and regional levels, to realize the Master plan of Indonesia's Economic Development Expansion and Acceleration (MP3EI) 2011-2025.

Various approaches have been implemented by Indonesian government to tackle the problem of unemployment and poverty. Among such enterprises [4] are Inpres Desa Tertinggal (IDT) program, Social Welfare of Business and Independent Young Family Group program (Prokesos KUBE KMM), Public Welfare Savings (Takesra), Public Welfare Business Loan (Kukesra), Small and Medium Enterprise Business Loan (KUKM), Social Security Network (JPS), and National Program of Independent Society Empowerment (PNPM Mandiri). Particularly, the Ministry of National Education has implemented various education programs for society, focused on the delivery of entrepreneurial skills which can be used as primary capital to work. The education programs include Public Entrepreneurial Education (PKM), Life Skills Education (PKH), and Vocational Village Development. However, all these programs have yet to shown positive and significant contribution towards solving the problems of unemployment and poverty.

In general, the implementation of entrepreneurship training tends to be partial. It only focuses on vocational skills, while ignoring other skills. Consequently, the trainees still find difficulties to develop their vocational enterprise into a proper business after the training. Other relevant studies concerning this matter are discussed in the reference [5-7].

\section{METHOD}

The present study is conducted using research and development design. It is appropriate considering that the aim of the study is to discover a suitable learning model with a focus on the framework of building CLC's independency.

Conceptually, the study serves as a framework for research and development. However, it has been modified and improved operationally. The steps of research and development [8] taken in the present study are: (a) information gathering (preliminary) observation, (b) planning, (c) formulating preliminary model design, (d) preliminary field testing, (e) revising the preliminary design, (f) main product field testing, (g) revising the main product, (h) operational field testing, (i) revising the operational product, (j) dissemination and retribution of model. For the first year of the study, the researcher only takes the steps until the stage of preliminary model design revision.

The sample of the study is five school dropout children who will be the target of entrepreneurship training at CLC Bina Cipta Ujungberung. Data and information gathered for the study include qualitative information, statistical data, and perceptional data; obtained using structured questionnaire, open-ended interview, and focus group discussion.

The study is conducted in the form of various training activities, including study of literature and need assessment, curriculum comparison study, exposition, focus discussion, individual work, group work, statistical data gathering, and questionnaire administration. Data is analyzed descriptively/narratively by focusing on its qualitative nature.

\section{RESULT AND DISCUSSION}

Community Learning Center (CLC) BINA CIPTA UJUNGBERUNG is located at 05 Andir Kaler, RT. 06/RW. 03, Cigending, Ujungberung Sub-district, Bandung City. The building is $10 \mathrm{~m} \mathrm{X} 12 \mathrm{~m}$ in area, standing on a $10 \mathrm{~m} \mathrm{X} 14 \mathrm{~m}$ land belongs to Yayasan Bina Cipta Ujungberung. It is founded on 14 May 2009, legalized through notary act No. 05/2014 and CLC License No. 421.10/3133-Disdik/2013, by Santi Susilawati, S.Pd.

CLC Bina Cipta Ujungberung was initially designed as a social program, supporting government's effort to build a society responsive towards information technology development. From Early Childhood Education institution in 2006, it then developed into a Community Learning Center by providing Functional Literacy program since 2009. In 2014, an Independent Business Group (KUM) that worked in accessory production was also added to the center. In line with the continuous effort of the government to realize the 9 year compulsory education program and its own attempt to equip future generation of the nation (particularly the adolescents), CLC Bina Cipta Ujungberung is one of the non-formal education institutions that work together with local society and regional government to build people's spirit and motivation to continue their learning, even though they have long passed the age of formal schooling.

To meet the requirement of 9 years compulsory education, CLC Bina Cipta Ujungberung focuses and serves poor people by providing Paket $A$ program (equivalent to elementary school), Paket $B$ program (equivalent to junior high school), and Paket $C$ program (equivalent to senior high school), as well as Functional Literacy program. The functions of the CLC are: as a center for community learning, as a meeting place of various existing and developing potentials in the community, as a source of information for community members who need functional skills, as a media to exchange knowledge and functional skills among the community members, and as a meeting place for community members who wish to improve themselves. It is realized that Community Learning Center (CLC) is highly crucial and necessary for the people with economic problems. CLC Bina Cipta Ujungberung provides these programs based on data gathered by Field Team of Community Education (TLD) and information from the head of RT 06 RW 03 Andir Kaler that there are quite a lot of school dropouts in the area. The factors that cause the high level of school dropouts in the area include socio-economic factor (which causes the people not to prioritize their children's education), not conducive environment, and the community's unawareness of the importance of education.

CLC Bina Cipta Ujungberung not only provides education and training programs. It also attempts to improve reading habit and interests among the people by creating a Community Reading Center in 2009, called TBM Rumah Baca Ujungberung. Other programs implemented by CLC Bina Cipta Ujungberung include health program and cultural program. The CLC cooperates with PKK cadres to perform monthly social 
activity of free health checkup for elderly people. It also provides traditional dance training, such as Jaipong, Rampak, and others.

Community Learning Center (CLC) Bina Cipta Ujungberung is still far from realizing its vision and missions, as well as its objectives. However, the supports from various concerned parties to help providing free educational services for poor people allow the CLC to provide solution and motivation for the poor people.

To answer the research question, the implementation of PBL model in entrepreneurial training for school dropouts is analyzed. On each phase of the training, problem-based learning begins with tutors reviewing preliminary knowledge needed to solve the problems, followed by presenting the problems. Each of the five participants presents a simple problem to the other participants. Then, all participants think of a solution to the problem and present it to the group. The next step involves the tutors providing guidance and mentoring to the participants to solve the problem. Through this process, tutors are able to identify the need of each participant. The identification serves as the basis for the formulation of training programs that suits participants' needs. The participants are then grouped based on similar problems, which will allow for easier process of training and problem solving. Tutors guide the participants as a group to handle their problems. Finally, tutors provide opportunities for the participants to evaluate the training and deliver their own conclusions.

\section{CONCLUSION}

The procedures of PBL model implementation in entrepreneurship training for school dropouts include reviewing and presenting problems in which the learners identify problems themselves and find solutions for the problems through experience and practices with various degree of success; developing appropriate strategy to solve problems through mentoring with the tutors; asking questions to support and encourage learners to finish their tasks; asking learners to discuss and evaluate the solutions to problems. It is concluded that entrepreneurship training for dropouts can be appropriately delivered using problem-based learning model.

\section{ACKNOWLEDGMENT}

The researcher would like to express her deep gratitude towards the CLC Bina Cipta Ujungberung who has provided an opportunity to conduct this research. She would also thank LPPM UPI who has funded the research.

\section{REFERENCES}

[1] Law No. 20/2003 on National Education System

[2] National Center of Statistics. 2012. Number of unemployed people in Indonesia 2012. Jakarta

[3] Research and Development Bureau. The 2011 Education Statistics Data. Jakarta: Kemdikbud.

[4] Law No. 4/1979 on Children Welfare

[5] Gonzalez, M, Heracleous M. Winters P. 2012. "Leaving the Safety Net: An Analysis of Dropouts in an Urban Conditional Cash Transfer Program. World Document Journal Vol 40 No 12 p. 2502-2521.

[6] Levy, Y. 2005. Comparing dropouts and persistence in e-learning courses. Journal of Computers\&Education Vol. 48 Issue 2, p. 185-204.

[7] Jukes, M, Jere, C and Prodmore P. 2014. Evaluating the provision of flexible learning for children at risk of primary school dropout in Malawi. International Journal of Educational Development Vol 39 p. 181-192.

[8] Bogdan, RC dan Biklen, SK. (1982). Qualitative Research for Education: Introduction to Theory and Methods. Boston: Allyn and Bacon 